\title{
The Melkite Community, Educational Policy and French Cultural Diplomacy: Archbishop Grigorios Hajjar and Mandatory Galilee
}

\author{
Charbel Nassif
}

The French Mandate over Syria and Lebanon was instituted by the League of Nations on April 25, 1920, after the First World War, did not slow France's desire to spread its cultural influence over Palestine, a territory under British mandatory rule. This linguistic and cultural rivalry thrived in a politically unstable region witnessing the emergence of competing nationalisms. While they maintained a belief in the superiority of their culture, the political and cultural situation left the French authorities concerned for their continued influence.

This chapter aims to analyse the recourse of the French, in the face of reduced political influence, to cultural diplomacy in its relations with the Melkite community. It asks how effective a means culture represented in France's efforts to influence the Melkites politically, particularly in the Eparchy of Akka in Mandate Palestine, which numbered around 20,000 people in 1924, scattered over 37 parishes, almost every parish with its own school. ${ }^{\perp}$ In particular, this chapter highlights the role of the Archbishop of Saint John of Akka, Grigorios Hajjar (1875-1940, in office 1901-1940), spearhead of the educational policy of the Melkite Arabic community, a man

\footnotetext{
${ }^{1}$ Jamil al-Bahri, "Akhbār Tā'īfiyya: ābrashīat 'Akkā," Al-Masarrah: majallat Batrìyarkìyat alRüm al-Käthutik I (1924): 56-59.

C. Nassif $(\triangle)$

The Netherlands and Centre de Documentation et de Recherches Arabes Chrétiennes (CEDRAC), Leiden University, Beirut, Lebanon
} 
of the Palestinian interwar period as well as a Francophone and Francophile personality.

Education was one of the cornerstones of French cultural diplomacy in the Middle East. To achieve French political ends would have been impossible without cooperation with the religious hierarchy who had the responsibility of establishing and maintaining schools. Thus, France sought to build ties with ecclesiastical structures in the Middle East, ties that seem to have been more effective and influential than those with secular structures, given the attachment of many Arabs to their respective religious affiliations.

The Melkites, present in Lebanon, Syria and Palestine, ${ }^{2}$ constituted a suitable target for France for a number of reasons. Capitulations had been granted by the Ottoman Empire to France for the protection of Eastern Catholics (including Melkites) in the Ottoman Empire, so the Melkites, united with Rome since 1724, had close ties with France and the French Consulate in Aleppo founded in the sixteenth century. They also had established relationships with the French missionaries (principally Jesuits and Lazarists) who had settled in the Middle East since the seventeenth century and were

\footnotetext{
${ }^{2}$ With small numbers also in Jordan and Egypt. Palestine is divided into the patriarchal eparchy of Jerusalem and the eparchy of Akka. The patriarchal eparchy covers Jaffa, Ramallah, Bethlehem, Beit Sahur, Beit Jala and Nablus, and the eparchy of Akka covers Haifa, Nazareth and all of Galilee. The eparchy of Akka was under the jurisdiction of the Patriarchate of Antioch until the patriarch Ignace Attieh yielded it, in 1626, to the Patriarchate of Jerusalem. In the patriarchate of Antioch, Eftimios Saïfi was consecrated archbishop of Sidon and Tyre in 1682. As a pro-Roman Catholic, he had succeeded in bringing together the faithful of Palestine who showed sympathy for the Roman Church. Towards the end of his life he even signed himself Archbishop of Sidon, Tyre and Akka. Saifi sent priests to look after the faithful of Akka, including his nephew Serafim Tanas who was put forward twice for the episcopate but rejected by the patriarch of Jerusalem. Elected Patriarch of Antioch in 1724, Tanas gave particular importance to Akka and the Galilee region. Because of the persecution carried out by the Orthodox in Syria and Lebanon after the split of 1724, Melkites and their priests began to emigrate to either Palestine or Egypt. In Palestine, they gathered in the north and along the coast to Jaffa under the protection of Zahir 'Umar al-Zaydani, who had managed to establish a quasi-independent principality. The Catholic Melkites of Akka fell under the eparchy of Sidon and Tyr until the election of Andraos Fakhoury in 1752. The archbishops of Akka did not always reside in their dioceses because of the persecutions of the Orthodox Patriarchate of Jerusalem and the Ottoman authorities. Following the death of Ahmad Pasha al-Jazzar in 1804, archbishop Makarios Nahas settled in his diocese. In 1772, the Propaganda entrusted to the Melkite patriarch of Antioch jurisdiction over all the Melkite Catholics in the patriarchate of Alexandria and Jerusalem. In 1837, the Melkite patriarch Maximos Mazloum obtained a firman which conferred the civil jurisdiction in the territory of the three patriarchates of Antioch, Alexandria and Jerusalem on him. In 1838, Rome granted Mazloum the title of Patriarch of Antioch, Alexandria, Jerusalem and all the East. The latter appointed Bishop Malatios Finde Patriarchal Vicar in Jerusalem. A Melkite cathedral was built near the Jaffa Gate and inaugurated in 1848 (Cathedral of the Annunciation). In 1883, the patriarchate bought the sixth stage of the Stations of the Cross, and built the Saint Veronica church in 1894 (Ilyas Kuwaytir, Al-Rubbānīya al-Mukballișīya manāra mushi'a fì al-arād̄ al-muqaddasa [Joun: Manshūrāt al-Yưbil al-Mi'awī al-Thalith lil-Ruhbānìah al-Mukhallisìyah, 1997], 96-84; No author, "Abrashīat Urshalīm al-batrīrkīa," Al-Masarrah [1939]: 385-399, $470-480)$.
} 
considered the primary cultural intermediaries of the French government. ${ }^{3}$ In addition to their relationships with the authorities and missionaries, the founding of the Seminary of Saint Anne in Jerusalem in 1881 was one of the outlets that France used to spread its cultural influence. Led by the Missionaries of Africa or "White Fathers", this seminary hosted young Melkites from Lebanon, Syria, Egypt and Palestine. ${ }^{4}$

\section{Melkite Archives for a Melkite Cultural History}

This chapter proposes a history of Melkites through their own archives instead of working from Roman Catholic archives or published literatures: these archives are those held at the patriarchal residence in Rabweh in Lebanon, at the Saint-Sauveur Monastery in Joun, and at the Melkite Patriarchate in Damascus. Opened for the first time to researchers, these archives contain many details related to the culture, education, political affairs and rights of the community, as well as information on the religious and parish life of the Melkite community. Examining these archives enables us to better perceive the cultural agenda of the Melkites and the use they made of cultural diplomacy to achieve their goals. This chapter does not claim to retrace the history of these archives. Nevertheless, this brief overview reveals, besides the loss of a large part of the archives, the importance of France, the French people and the French language in the cultural life of the Melkites.

\section{The Archives of the Patriarchal Residence: Rabweh}

This archive contains the patriarchal correspondence register of Patriarch Dimitrios Qadi, recording letters sent between 1921 and 1925 to the Roman Curia, to France and to the Mandatory authorities in Lebanon and Syria. It also holds the correspondence of the Archbishop of Saint John of Akka, Grigorios Hajjar, with the ruling Patriarchs between 1901 and 1940. This is collected in two folders, each of which consists of three files. The recipient is always-unless otherwise stated — the Melkite Patriarch. ${ }^{5}$ The documents are not always organised in chronological order. It often happens that Hajjar does not date his letters. The ink is erased in some letters, hence the difficulty

\footnotetext{
${ }^{3}$ Jennifer Dueck, "International Rivalry and Culture in Syria and Lebanon Under the French Mandate," in Searching for a Cultural Diplomacy, eds. Jessica Gienow-Hecht and Mark Donfried (New York: Berghahn, 2010), 146.

${ }^{4}$ Philippe Gorra, Sainte-Anne de Jérusalem Séminaire grec melkite dirigé par les Pères Blancs à l'occasion du son cinquantenaire (1882-1932) (Harissa: Press Saint Paul, 1932); Nicolas Dahbar, Sainte-Anne de Jérusalem Séminaire grec-melkite dirigé par les RR. PP. Blancs à l'occasion du $75^{e}$ anniversaire de sa fondation (1882-1957) (No location: No publisher, 1959); Dominique Trimbur, "Sainte-Anne: lieu de mémoire et lieu de vie français à Jérusalem," Chrétiens et sociétés $X V I^{e}-X X^{e}$ siècles 7 (2000): 39-69.

${ }^{5}$ Pierre IV Graigiry (1898-1902); Cyril VIII Geha (1902-1916); Dimitrios I Qadi (19191925); Cyril IX Moghabghab (1925-1947).
} 
in reading some excerpts. Some of the correspondence is in French, but the bulk of it is in Arabic.

The first patriarchal residence in Lebanon was the monastery of Our Lady of the Annunciation at Ayn Trāz, built in 1811. Equally conceived of as a seminary to train Melkite seminarians, this monastery held manuscripts, printed theological and philosophical works, and the correspondence of the Melkite Patriarchs with the civil and religious authorities. The monastery was burned and pillaged by the Druze on 20 October 1841 before being stocked again under the care of Patriarch Grigorios Sayyour (1864-1897) and the generosity of the French abbé Damourat, who offered four chests of French books. ${ }^{6}$ During the Lebanese Civil War, the monastery was looted and burned again in spring 1983, resulting in the loss of a large section of the library and the patriarchal archives. The new patriarchal residence established in Rabweh in 1977 holds the rest of the archives as well as the rest of the documents retrieved or collected over the course of time. This consists of about ten manuscripts, part of the registers of the Patriarchs and the personal correspondence of archbishops and some priests with the reigning Patriarch.

\section{Library of the Monastery of Saint-Sauveur: Joun}

The archives concerning Hajjar were probably imported from Saint John of Akka by a Salvatorian monk, this collection is very well preserved and has been numerised and classified recently. In addition to ordinary correspondence, these records show that the inhabitants of his see often referred to Hajjar for advice on civic matters: purchase of land, disputes, opinion concerning marriage, asking for alms and employment requests, especially in Hajjar's schools (ASS 1, fol. 42-63, 64, 65) but also as sacristan or cantor. The archives also contain the texts of Hajjar's spiritual retreats, a book of anecdotes collected by Hajjar, all papers pertaining to his 25 th episcopal jubilee (1925) and his funeral, as well as several printed pamphlets on his works.

The origins of the archives of Monastery of Saint-Sauveur date back to the founder of the Salvatorian Basilian Order, archbishop Eftimios Sayfi (16431723), known for his vast knowledge of science and his literary works. The copyists abounded in this monastery in the seventeenth and eighteenth centuries, but it was looted and destroyed in 1777. Subsequently, two monks were sent to France to finance the acquisition of new books, carrying letters of recommendation from the French consul in Sidon. The monastery was again looted and burned by the Druze in 1860; the fire persisted for three days. During the Lebanese Civil War, the monastery was bombarded in 1985

\footnotetext{
${ }^{6}$ Wisām Bishārah Kabkab, Ayn Trāz, 1811-2004: Iklīrīkīyat Sayyidat al-Bishārah al-Batriyarkīyah wa-al-maqarr al-Bațīyarkī (Rabwah: Markaz al-Abhāth al-Malakīyah, 2008), 123-129.
} 
and then occupied until the year 1990. Some manuscripts and archives were saved and the Salvatorian Basilian order endeavoured to recover the rest of the manuscripts. 2884 of the library's manuscripts have been digitised. ${ }^{7}$

\section{Archives of the Melkite Patriarchate: Damascus}

The archives in Damascus contain 191 digitised manuscripts, a hundred account registers and inventories, ${ }^{8}$ and the patriarchal registers of the Patriarchs Cyril VIII Geha (1902-1916), Demetrios Qadi (1919-1925) and Cyril Moghabghab (1925-1947). These valuable texts constitute the primary sources for any research on the history of the patriarchate in the twentieth century. The archival room also contains Arabic books printed in the nineteenth century and a selection of French books published in the eighteenth and nineteenth centuries. ${ }^{9}$ There are also two small collections of large-format photos of Patriarch Cyril Moghabghab, the 25th anniversary of Grigorios Hajjar's (1927) episcopal jubilee and some photos of the Sainte-Anne Seminary and other prelates.

\section{Educating the Melkites À la FrançAise}

The French language was widespread amongst the Melkites many years before the French Mandate over Lebanon and Syria as a result of a number of close links. By way of example, in January 1629, the Jesuit Jérôme Queyrot started a school at the Melkite headquarters in Aleppo, immediately attracting over thirty students. ${ }^{10}$ Between 1831 and 1834, two Francophone Jesuit priests and a brother also supported Archbishop Maximos Mazloum in managing the Ayn Trāz seminary. ${ }^{11}$ In addition to founding the Saint Anne Seminary in Jerusalem, in 1900 the French government offered two places for young Melkites to continue their philosophical and theological formation at the

\footnotetext{
${ }^{7}$ Faez Freijat, "La biblioteca del convento de San Salvador (Ğūn)," in Manuscritos árabes del Libano, Encuentro de culturas, religions y saberes, ed. Philippe Roisse (Beirut: Cedrac, 2010), $57-72$.

${ }^{8}$ These are often tables showing the expenses and income of the patriarchate as well as the inventories of several patriarchal institutes or foundations (Patriarchate-Damascus, Patriarchal College-Damascus, Patriarchal College-Beirut, Abra waqfs, charitable associations).

${ }^{9}$ Vie des saints (1880); Histoire de l'Église (1843); Histoire du monde universelle, 10 volumes (1866); Abrégé de l'histoire ancienne de Rollin, 5 volumes (1826); Abrégé de l'histoire romaine de l'abbé Tailhé, 5 volumes (1827); Histoire romaine de Rollin, 16 volumes (1758); Histoire ancienne de Rollin, 13 volumes (1735); Histoire du bas empire, 27 volumes (published between 1752 and 1817); La vie des saints, 12 volumes (1884); Beauté de l'histoire de Turquie (1818).

${ }^{10}$ Abdallah Raheb, Conception de l'union dans le patriarcat orthodoxe d'Antioche (1622-1672) (Rome: Pontificia Universitas Gregoriana, 1981), 54.

${ }^{11}$ Effectively, this seminary only received seminarians in 1833 . The Jesuits left the seminary in January 1834 (Kabkab, Ayn Trāz, 39-48).
} 
Saint-Sulpice seminary in Paris. ${ }^{12}$ And in 1924 , another seminarian was being trained at the seminary in Marseille. ${ }^{13}$ Alongside the role of French in formal religious education, the chronicles in the Paulist fathers' journal Al-Masarrah often evoke the French plays performed by the seminarians of Saint Anne and by other schools in Aleppo, Damascus, Beirut and Haifa. They also recount the poems and the speeches delivered in French on various occasions. ${ }^{14}$

By the beginning of the twentieth century, the French state was making the importance it attached to Francophonie publicly apparent. In 1911, Patriarch Cyril Geha was decorated by the French government for the services he had rendered to his church for 27 years, and especially for having favoured the French language in the patriarchal schools of Beirut, Damascus and Egypt. ${ }^{15}$ During the ceremony, the consul evoked Geha's efforts to elevate the place of education and its virtues. Geha responded by recalling the good deeds of France in encouraging education in the first place, and then his friendship with the Ottoman Empire and its protection of the Eastern Catholic churches, particularly the Melkites. ${ }^{16}$ Education, Geha's example demonstrates, occupies a primordial place in Franco-Melkite relations.

After the French Mandate, the Syrian and Lebanese populations did not in general perceive culture as part of a political project and thus did not associate it with negative images of imperialism or felt the need to resist it as part of their nation-building projects. ${ }^{17}$ The Melkites continued to teach French in their schools, and French remained, along with Arabic, a language of correspondence among Melkite clergymen. During his inauguration speech in 1921, the new Archbishop of Beirut, Bassilios Qattan, told the representatives of the French Mandate: “Syria's relations with your noble fatherland

\footnotetext{
${ }^{12}$ Rabweh, PM, DQ fol. 114. Henceforth, the following abbreviations are used in footnotes: $\mathrm{PM}=$ Melkite Patriarchate; $\mathrm{DQ}=$ Dimitrios Qadi; $\mathrm{GH}=$ Grigorios Hajjar; ASS = Archives Saint-Sauveur.

${ }^{13}$ Rabweh, PM, Reg. DQ, 269. Letter sent to the Superior of the Major Seminary of Marseille on July 17, 1924.

${ }^{14}$ During the sacerdotal jubilee of the patriarch Cyril VIII Geha, organised in Damascus on June 12, 1910, a poem in French was read by Father Elias Batarekh in the name of the patriarchal clergy. The next day, a French play was performed at the patriarchate in the presence of the French consul. On 16 July 1911, the students of the Melkite school in Aleppo performed a play entitled 'Būvīn', with very good French pronunciation, in the presence of the French consul (this may have been a dramatisation of the Battle of Bouvines, 1214, in which a French army defeated a force commanded by the Holy Roman Emperor). A play on the feast of Saint Gregory (1912) at Haifa was performed with a good accent in French (Ighnātius Qarūshān, "Ḥaflat yūbīl ghibțat abīna al-bațriyark kirillūs al-thāmin al-kūlliyyi al-țūbā," Al-Masarrah 3 [1910]: 86; No author, "mukātabāt," Al-Masarrah 6 [1911]: 239; Būlos Sayyūr, "mukātabāt," Al-Masarrah 18 [1912]: 717).

${ }^{15}$ No author, "mukātabāt," Al-Masarrah 6 (1911): 238.

${ }^{16}$ Ilyas Batārikh, "Ḥaflat taslīm wisām jawqat al-sharaf li ghibțat baṭiyarkina al-kūlliyyi al-tūbā," Al-Masarrah 8 (1911): 313-317.

${ }^{17}$ Dueck, "International rivalry and culture," 139.
} 
[...] can be summed up in a few words: protection, charity, education". ${ }^{18}$ This sentence testifies to the importance that France accorded to the promotion of education and the teaching of French. In the same year, the High Commissioner awarded 1200 gold pounds to repair the schools in the Midan area of Damascus, which had been damaged by the Turks in WWI. ${ }^{19}$ In 1922, Patriarch Dimitrios Qadi thanked the French Alliance for the sum of 400 francs paid to the Melkite patriarchate:

For a very long time our families in Damascus held for France a love that one vows to a country of adoption. Since the French Mandate our attachment became stronger and our love more ardent. Our children give themselves with more passion to study French. They make ever constant progress in it. ${ }^{20}$

Also in 1922, the Ministry of Foreign Affairs paid 30,000 francs to support the works of the Melkite Patriarch. ${ }^{21}$ In 1923, the Patriarch also received a sum allocated to his schools by the Directorate of Public Instruction and the following year, l'Euvre des Écoles d'Orient sent him 24,000 francs for the schools of the Melkite dioceses. According to the letter sent by Qadi, the diocese of Saint John of Akka received 2000 francs. $^{22}$

Even the Patriarch Dimitrios Qadi, who died in 1925, wrote his will in French, and filed three copies at the French consulate in Alexandria, the French legation in Cairo and the High Commission in Damascus. ${ }^{23}$ This Francophone ambiance within the Melkite Patriarchate extended beyond the French mandatory territories, however, and was not unfamiliar to the diocese of Akka in British-ruled Palestine.

\section{Grigorios HajJar: Bishop of the Arabs and Prince of Preachers}

Dubbed by Melkites the Bishop of the Arabs and other superlative titles, Grigorios Hajjar is best known both in the popular Melkite memory and in the academic literature on Mandate Palestine as the charismatic leader of the Melkite community in northern Palestine. ${ }^{24}$ Invested as Archbishop of Saint

\footnotetext{
${ }^{18}$ Basīlius Qattān, "Khūtāb siyādat al-mutrān kīriūs Basīliyus Qattān mitrupulīt Bayrūt wa Jūbayl wa tawābi'ihimā," Al-Masarrah 5 (1921): 220.

${ }^{19}$ Rabweh, PM, Reg. DQ, 201.

${ }^{20}$ Rabweh, PM, Reg. DQ, 214.

${ }^{21}$ Rabweh, PM, Reg. DQ, 218. Letter sent in January 1923 to the Minister of Foreign Affairs.

${ }^{22}$ Rabweh, PM, Reg. DQ, 269. Letter sent on May 24, 1924 to the Secretary General of the Work of the Schools of the East, M. Desmonts.

23 “Testament de S.B. Dimitrios Cadi," Al-Masarrah 11 (1925): 709-710.

${ }^{24}$ See, for example, the brochure of the Monastery of Saint-Sauveur, where Hajjar was ordained, and which says of him that he was "rightly called Amir (Prince) of Preachers... Bishop of the Arabs and Christ of the Orient" (Basilian-Salvatorian Order, Monastery of St Saviour, trans. K. Mortimer [Joun: Deir al-Moukhaless, n.d.], 15).
} 
John of Acre in 1901, he was an open Francophile even at times of Ottoman confrontation with France. During WWI, the Ottoman authorities sentenced him to death (in absentia), accusing him of having recruited Arab youths for the French army. ${ }^{25}$ Under British colonial rule, he remained an outspoken advocate of Palestinian and Arab nationalisms, a campaigner for Arab political unity who worked with the mainstream Palestinian nationalist leadership and was affiliated with the network of Muslim-Christian Associations. ${ }^{26}$ Of the regional church leaderships in the Haifa and the Galilee, he seems to have attached most importance to political unity with Islamic communities. ${ }^{27}$ These views did not, however, preclude occasional opposition to and conflict with Islamic organisations in Haifa and with the Islamic press in Mandate Palestine, and assertion of Christian rights in communications to the leadership of the national movement. ${ }^{28}$

Hajjar was killed in a car crash on the road to Haifa in November 1940; his cortege was described at the time-perhaps with an implicit comparison to the large numbers at that of Islamic leader 'Izz al-Din al-Qassam in $1935^{29}$ — as "one of the most impressive funerals ever witnessed in Haifa". ${ }^{30}$

\section{Hajjar's Educational Policy in Galilee}

In much of the scholarly literature, Grigorios Hajjar is a monolithic figure associated primarily with nationalist politics. However, as the internal documents of the Melkite church emphasise, one of his most important areas of activity was actually the expansion of education to the Melkite population under his care. Given that France lost its direct political influence in Palestine at the beginning of the British Mandate, it sought to consolidate its influence by supporting Melkite schools, whose works were complementary to French schools. Education thus acquired a primary importance in Franco-Melkite relations: "For schools and seminaries, full and complete freedom! We cannot complain". ${ }^{31}$ Grigorios Hajjar, meanwhile, sought to fight illiteracy and founded schools in every town and village, even if they had only a small number of inhabitants, and the resources made available in the French pursuit of its cultural and political aims made many of his educational projects possible.

\footnotetext{
${ }^{25}$ Mahmoud Yazbak, Haifa in the Late Ottoman Period, 1864-1914: A Muslim Town in Transition (Leiden: Brill, 1998), 211.

${ }^{26}$ Noah Haiduc-Dale, Arab Christians in British Mandate Palestine: Communalism and Nationalism 1917-48 (Edinburgh: Edinburgh University Press, 2013), 33, 42, 154.

${ }^{27}$ Haiduc-Dale, Arab Christians, 104, 106.

${ }^{28}$ See chapters by Maggiolini and Hillel in this volume; also, Haiduc-Dale, Arab Christians, 46,153 .

${ }^{29}$ Beverley Milton-Edwards, Islamic Politics in Palestine (London: I.B. Tauris, 1999), 19.

${ }^{30}$ Haiduc-Dale, Arab Christians, 184.

${ }^{31}$ Rabweh, PM, Reg. DQ, 283. Letter sent to the director of the seminary of Saint Sulpice, abbé Vigourel, by Patriarch Demetrios Qadi.
} 
The episcopate of Grigorios Hajjar is particularly marked by the founding of schools known as the Hajjar Schools, and the record of Melkite schooling under his care is shown in the accompanying table. ${ }^{32}$ Establishing a school was not always an objective in itself. It was also a means to win the Orthodox over to the Melkite Church on the one hand, ${ }^{33}$ and to keep the Melkites away from other non-Catholic denominations on the other. ${ }^{34}$ In 1905, Hajjar clearly evokes with the Patriarch the need to open at least 30 schools to fight the proselytism of Protestants and Russian Orthodox missionaries. ${ }^{35}$ The construction of schools was also a means to avoid the Latinisation of Melkite children attending Latin schools. The Melkites built schools in Haifa, Saint John of Akka and Shefa-'Amr, where the Latins already had flourishing educational establishments. In Tiberias, Melkites were forbidden to send their children to the school of the Italian sisters, under penalty of being refused the sacraments. ${ }^{36}$

In a pamphlet on the Melkite Church in Galilee published in 1890, Jean de Sarepta mentions the presence of French schools run by the Frères des écoles chrétiennes, whose zeal and talent "are above all praise", alongside the Italian schools directed by the Franciscans. De Sarepta deplores the absence of Melkite schools for lack of financial resources but is optimistic, hoping that the Latins and France will come to the aid of the Melkites. ${ }^{37}$

The arrival of Grigorios Hajjar in Akka gave impetus to the parish and cultural life of the diocese. In addition to literary Arabic, which he mastered perfectly, Hajjar had learned French, Italian, Latin and ancient Greek at the Monastery of Saint-Saveur in Joun. During his stay in Egypt, he taught Arabic at the School of the Christian Brothers in Choubra, which allowed him to perfect his French as well as to learn English. ${ }^{38}$ Becoming the Melkite archbishop of Saint John of Akka in 1901, Hajjar accorded great importance to the construction of schools in his diocese, whose territory covered Upper and Lower Galilee (including the cities of Akka, Haifa, Nazareth, Tiberias and

\footnotetext{
${ }^{32}$ Or the Catholic episcopal schools.

${ }^{33}$ Rabweh, PM, GH rapport 1939, 5.

${ }^{34}$ Grigorios Hajjar, Mes auvres en 1936 (No publisher known), 11: "I do not speak of the schools to open in the various countries that are deprived of them, where our children are exposed to all dangers in the midst of so many religions and sects that coerce them on all sides." In a letter sent to an American bishop on December 29, 1928: "It must not be that these flocks remain the prey of the ravening wolves who run constantly around the herd." ASS 3, fol. 13.

${ }^{35}$ Rabweh, PM, GH 1.1 fol. 22.

${ }^{36}$ ASS 3, fol. 31, 33 .

${ }^{37}$ Jean de Sarepta, L’Eglise catholique-grecque en Galilée (Paris: Imprimerie de F. Levé, 1890), $49-51$.

${ }^{38}$ Ilyas Kuwaytir, Al-akimma al-nayyira (Joun: Manshūrāt al-Yübil al-Mi'awī al-Thăith lil-Ruhbānìyah al-Mukhallisīyah, 1993), 295; Qusțanțin Bāsha, Tārikh al-tayyib al-athar Ghrighorios

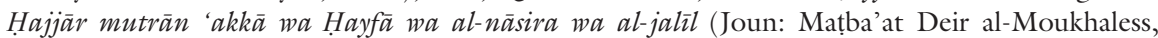
1941), 19.
} 
Safed), and which brought together, upon his death in 1940, 20,500 faithful distributed in 40 churches served by 42 priests. ${ }^{39}$

In 1901, there was only one school in Akka and two small schools in Haifa and Shefa-'Amr ${ }^{40}$; Hajjar thus proceeded immediately to the construction of schools. During his ad limina visit in 1903, Hajjar presented Pope Pius X with a report in which he indicated that the maintenance of the ten entirely free schools cost him 5000 francs and that he still had to create ten more for boys and twenty for girls. Among the resources to support the needs of his diocese, he mentions the French government and the Euvre des Écoles d'Orient which granted him, respectively, 3000 and 400 francs. In another letter addressed to the Patriarch in 1910, Hajjar mentions having 37 large and small schools. ${ }^{41}$ Between 1901 and 1918, Hajjar founded 43 schools, the majority of which were for boys. ${ }^{42}$

During the First World War, Hajjar did his best to keep schools open and dispense education in the French language. In 1919, the number of schools reached 50. In 1920, Hajjar noted that he had opened 22 schools out of the 50 that were under his care before the war. ${ }^{43}$ In 1927, Jamil al-Bahri mentions that these schools admitted at least 3000 pupils. ${ }^{44}$ In 1928, we count 29 schools. ${ }^{45}$ In a report on his works in 1929, Hajjar mentions having 33 large and small schools at which tuition was free or at very low cost and that he hopes to open another 50, also charging little or no fees. As for the number of children enrolled in schools, this reached 2000 in $1936 .{ }^{46}$ In 1939, the budget for these 28 schools, large and small, amounted to 2000 Palestinian pounds, for schools ranging from a single teacher to those of towns and cities such as Haifa, Shefa'Amr and Nazareth with up to eight or twelve teachers each (Table 1). ${ }^{47}$

References: Statistics of the eparchy of Akka (ASS 1, fol. 74-75). "Nomenclature des églises, cures, écoles et œuvres diverses érigées et crées

\footnotetext{
${ }^{39}$ Rabweh, PM, GH rapport 1939, 1.

${ }^{40}$ The eparchy had only one school in Akka and a couple minor ones in two villages under the eparchy. In no school affiliated to the community other than in the Akka School that grammar, syntax, vocabulary, mathematics, catechism and language were taught except in its analogous, perhaps to a lesser extent, school in Haifa, and similarly in Shafa 'Amr. Jamil al-Bahri, Ghrighorios Hajjōr mitrupulìt'akkā wa Hayfā wa al-nāsirah wa sa'ir al-jal̄̄l tarjamatahū a'mā $\bar{u} \bar{u} h \bar{u}$ (Haifa: Maṭba'at al-zahra, 1927), 9.

${ }^{41}$ Rabweh, PM, GH 1.1 fol. 62.

${ }^{42}$ In 1909, there were 34 schools. In the 1939 report, Hajjar mentions that there were 45 schools before the war. Rabweh, PM, GH rapport 1939, 1; Rapport des auvres de S.G. Mgr Grigorios Haggear, archevêque catholique de la Galilée 1903 et 1909, 6.

${ }^{43}$ Rabweh, PM, GH 1.2 fol. 20. Letter of Hajjar to Patriarch Qadi, 27th December 1920.

${ }^{44}$ Al-Bahri, Ghrighorios Hajjā $r, 11$.

${ }^{45}$ ASS 3 , fol. 14.

${ }^{46}$ Hajjar, Mes auvres en 1936, 6.

${ }^{47}$ Grigorios Hajjar, Rapport succinct contenant les réponses an questionnaire qui m'a été adressé par S.B. Monseigneur notre Vénéré Patriarche Cyrille IX, 1939. Rabweh, PM, GH rapport 1939,1 .
} 
Table 1 Melkite schools of the eparchy of Akka under Grigorios Hajjar

\begin{tabular}{|c|c|c|c|c|c|}
\hline Location & $\begin{array}{l}\text { Number of } \\
\text { schools }\end{array}$ & Established & $\begin{array}{l}\text { Students, } \\
1927\end{array}$ & $\begin{array}{l}\text { Number of } \\
\text { Melkites, } \\
1929\end{array}$ & Additional information \\
\hline $\begin{array}{l}\text { Saint John of } \\
\text { Akka }\end{array}$ & 1 & Before 1900 & & 400 & $\begin{array}{l}\text { French language courses } \\
\text { provided }\end{array}$ \\
\hline Haifa & 1 (boys) & 1904 & 206 & 5000 & $\begin{array}{l}\text { Large school run by the } \\
\text { French nuns of Notre } \\
\text { Dame de Nazareth-202 } \\
\text { students in 1939. French } \\
\text { language courses provided }\end{array}$ \\
\hline $\begin{array}{l}\text { Caîffa (Haifa) } \\
\text { suburbs }\end{array}$ & 1 & $\begin{array}{l}\text { Around } \\
1923\end{array}$ & & & Presbytery school \\
\hline Esfiat & $\begin{array}{l}2 \text { (one each, } \\
\text { boys and } \\
\text { girls) }\end{array}$ & $\begin{array}{l}\text { Between } \\
1901 \text { and } \\
1918\end{array}$ & & 150 & Presbytery school \\
\hline Jdaideh & $\begin{array}{l}2 \text { (one each, } \\
\text { boys and } \\
\text { girls) }\end{array}$ & $\begin{array}{l}\text { Between } \\
1901 \text { and } \\
1918\end{array}$ & & 66 & Presbytery school \\
\hline Macre & l (boys) & $\begin{array}{l}\text { Between } \\
1901 \text { and } \\
1918\end{array}$ & & 59 & $\begin{array}{l}\text { School rented and main- } \\
\text { tained by Hajjar }\end{array}$ \\
\hline Chaab & 1 (boys) & $\begin{array}{l}\text { Between } \\
1901 \text { and } \\
1918\end{array}$ & & 50 & Built by Hajjar \\
\hline $\begin{array}{l}\text { Abelline } \\
\text { (Ibelin) }\end{array}$ & $\begin{array}{l}2 \text { (one each, } \\
\text { boys and } \\
\text { girls) }\end{array}$ & Before 1914 & & 135 & Leasehold. Closed in 1914 \\
\hline Shefa-'Amr & 1 (boys) & 1901 & 148 & 1300 & $\begin{array}{l}\text { School run by the French } \\
\text { nuns of Notre Dame de } \\
\text { Nazareth. } 200 \text { students } \\
\text { before and after World War } \\
\text { I-7 teachers. French lan- } \\
\text { guage courses provided }\end{array}$ \\
\hline $\begin{array}{l}\text { Jaffa of } \\
\text { Nazareth }\end{array}$ & $\begin{array}{l}2 \text { (boys and } \\
\text { girls) }\end{array}$ & Before 1914 & & 213 & $\begin{array}{l}\text { School for boys built by } \\
\text { Hajjar and school for girls } \\
\text { maintained by Hajjar. } \\
\text { Closed in } 1914\end{array}$ \\
\hline Beineh & $\begin{array}{l}2 \text { (boys and } \\
\text { girls) }\end{array}$ & $\begin{array}{l}\text { Between } \\
1901 \text { and } \\
1918\end{array}$ & & 140 & Leasehold. Closed in 1926 \\
\hline $\begin{array}{l}\text { Cana of } \\
\text { Galilee }\end{array}$ & $\begin{array}{l}2 \text { (boys and } \\
\text { girls) }\end{array}$ & $\begin{array}{l}\text { Between } \\
1901 \text { and } \\
1918\end{array}$ & & & $\begin{array}{l}\text { Built by Hajjar } \\
\text { Presbytery school }\end{array}$ \\
\hline Tauraan & $\begin{array}{l}2 \text { (boys and } \\
\text { girls) }\end{array}$ & $\begin{array}{l}\text { Between } \\
1901 \text { and } \\
1918\end{array}$ & $\begin{array}{l}32 \text { boys } \\
18 \text { girls }\end{array}$ & 220 & $\begin{array}{l}\text { Presbytery school. French } \\
\text { language courses provided }\end{array}$ \\
\hline Sirine & l (boys) & $\begin{array}{l}\text { Between } \\
1901 \text { and } \\
1918\end{array}$ & & 80 & $\begin{array}{l}\text { Leasehold. Presbytery } \\
\text { school }\end{array}$ \\
\hline Tiberias & $\begin{array}{l}2 \text { (boys and } \\
\text { girls) }\end{array}$ & 1900 & & 300 & \\
\hline
\end{tabular}


Table 1 (continued)

\begin{tabular}{|c|c|c|c|c|c|}
\hline Location & $\begin{array}{l}\text { Number of } \\
\text { schools }\end{array}$ & Established & $\begin{array}{l}\text { Students, } \\
1927\end{array}$ & $\begin{array}{l}\text { Number of } \\
\text { Melkites, } \\
1929\end{array}$ & Additional information \\
\hline Ailaboune & $\begin{array}{l}2 \text { (boys and } \\
\text { girls) }\end{array}$ & $\begin{array}{l}\text { Between } \\
1901 \text { and } \\
1918\end{array}$ & $\begin{array}{l}40 \text { boys } \\
35 \text { girls }\end{array}$ & 245 & \\
\hline Deir Hanna & $\begin{array}{l}2 \text { (boys and } \\
\text { girls) }\end{array}$ & $\begin{array}{l}\text { Between } \\
1901 \text { and } \\
1918\end{array}$ & 22 & 135 & Leasehold \\
\hline Arrabeh & 1 (boys) & $\begin{array}{l}\text { Between } \\
1901 \text { and } \\
1918\end{array}$ & 12 & 55 & \\
\hline Sakhnin & l (boys) & $\begin{array}{l}\text { Between } \\
1901 \text { and } \\
1918\end{array}$ & 36 & 112 & \\
\hline Moughar & $\begin{array}{l}2 \text { (boys and } \\
\text { girls) }\end{array}$ & $\begin{array}{l}\text { Between } \\
1901 \text { and } \\
1918\end{array}$ & 35 girls & 1600 & \\
\hline Safed & l (boys) & $\begin{array}{l}\text { Between } \\
1901 \text { and } \\
1918\end{array}$ & & 350 & $\begin{array}{l}\text { French language courses } \\
\text { provided }\end{array}$ \\
\hline Djische & $\begin{array}{l}2 \text { (boys and } \\
\text { girls) }\end{array}$ & $\begin{array}{l}\text { Between } \\
1901 \text { and } \\
1918\end{array}$ & & & Leasehold \\
\hline Fassouta & $\begin{array}{l}2 \text { (boys and } \\
\text { girls) }\end{array}$ & $\begin{array}{l}\text { Between } \\
1901 \text { and } \\
1918\end{array}$ & 43 boys & 534 & $\begin{array}{l}\text { Leasehold. French lan- } \\
\text { guage courses provided }\end{array}$ \\
\hline Sahmata & l (boys) & $\begin{array}{l}\text { Between } \\
1901 \text { and } \\
1918\end{array}$ & & 40 & \\
\hline Maaliya & 1 (boys) & $\begin{array}{l}\text { Between } \\
1901 \text { and } \\
1918\end{array}$ & $\begin{array}{l}37 \text { boys } \\
25 \text { girls }\end{array}$ & 500 & $\begin{array}{l}\text { French language courses } \\
\text { provided }\end{array}$ \\
\hline Tarchiha & l (boys) & $\begin{array}{l}\text { Between } \\
1901 \text { and } \\
1918\end{array}$ & 39 & 400 & $\begin{array}{l}\text { French language courses } \\
\text { provided }\end{array}$ \\
\hline Bassa & 2 (boys) & $\begin{array}{l}\text { Between } \\
1901 \text { and } \\
1918\end{array}$ & & 800 & $\begin{array}{l}\text { Large rented school and } \\
\text { a boarding school for } \\
\text { the students from Jenin, } \\
\text { Qalqilya, Nablus and } \\
\text { other villages of Galilee, } \\
\text { run by the French nuns of } \\
\text { Notre Dame de Nazareth. } \\
\text { Secondary school_gradu- } \\
\text { ated students could pursue } \\
\text { university studies. French } \\
\text { language taught }\end{array}$ \\
\hline Nazareth & & & 130 & & \\
\hline Damoun & & & 1 & & \\
\hline Be'ine? & 1 & & & & $\begin{array}{l}\text { Presbytery school built in } \\
1935\end{array}$ \\
\hline
\end{tabular}


depuis mon arrivée et ma prise de possession du Siege Archiépiscopal de Saint-Jean-D'acre, Haifa, Nazareth et de toute la Galilée," typewritten text of 42 pages prepared by Grigorios Haggear in Rome, 28 June 1926. Statistics of the Melkite Episcopal Schools in the eparchy of Akka in 1927: Johnny Manșūr, Ru'ya mū'àsira lihayāt wa a'māl al-mutrān Gbrigurius Hajjar (Haifa: No publisher, 2013), 109-111; Qusțanținn Bāsha, Tārikh al-țayyib alathar (Joun: Mațba'at Deir al-Moukhaless, 1941), 54-66.

\section{French in the Melkite Schools}

What about the teaching of French in these schools? In fact, only some schools provided French classes. According to an undated letter to the Director of Public Education, Hajjar lists eleven schools with about 1,025 students and mentions that he cannot find French teachers for the other schools. ${ }^{48}$ In 1913, the Melkite schools of Haifa, Nazareth, Akka and Shefa-'Amr were entirely managed by the French nuns of Notre Dame de Nazareth. ${ }^{49}$ In 1924 French, which had the status of a semi-official language, was no longer recognised as the language of examination for all school institutions. ${ }^{50}$ This may justify the limited number of Melkite schools that taught French. Nevertheless, French remained a language of prestige often reserved for the most affluent social classes and within the ecclesiastical milieu. ${ }^{51}$ The Melkites of Palestine also read French Catholic newspapers. When an American missionary wanted to found a branch of the Protestant YMCA in Haifa, the inhabitants were favourable to the idea until they read in La Croix (January 6, 1921) the prohibition from the Holy See on joining this association. Subsequently, Hajjar asked his flock to leave this non-Catholic association. ${ }^{52}$

The number of schools, students and other data mentioned in the table must be considered with caution, especially since this information is often evoked to appeal to donors. This suggestion appears in a long letter written in 1913 by the vicar of the Latin parish of Haifa, criticising Hajjar's work. The author notes that "having many schools is a title to ignite generosity in Europe". According to this letter almost all Melkite parishes had a boys' school and a girls' school, but the writer alleges that: "by schools, I mean

\footnotetext{
${ }^{48}$ Probably after 1927. ASS 1, fol. 52 Haifa: 300; Saint John of Akka 50; Shefa-'Amr 130; Nazareth 125; Safed 50; Bassa 100; Maalia 70; Tarchiha 50; Fassouta, 50; Barco of Galilee 40; Touranne 60 .

${ }^{49}$ ASS 3, fol. 29-38.

${ }^{50}$ Karène Sanchez Summerer, "Le triptyque 'Langue - Education - Religion' dans les écoles missionnaires françaises de Jérusalem en Palestine ottomane et mandataire," Sociolinguistica 25 (2011): 67 .

${ }^{51}$ Karène Sanchez Summerer, "Les catholiques palestiniens et la langue française (18701950)," Documents pour l'histoire du français langue étrangère ou seconde 45 (2010): 7.

${ }^{52}$ The decree of the secretary of the Congregation of the Holy Office, Cardinal Rafael Merry del Val promulgated on November 5, 1920. Jamil al-Bahri, "Akhbār Tā'îfiyya: ābrashīat 'Akkā," Al-Masarrah 3 (1921): 138-139; Acta Apostolicae Sedis 12 (1920): 595-597.
} 
small rooms. For how many students? Except for the cities of Haifa, Saint John of Akka and Shefa-'Amr, except as well for the villages maintained by the Lazarists $[. .$.$] , we count very few pupils or almost none". The author of$ the letter also claims that Hajjar "presents his schools to Paris, with the government, as secular schools in order to receive a subsidy". ${ }^{53}$ These comments are a corrective to the Melkite hierarchy's stories of success, but must also be understood through the lens of inter-denominational rivalries and the competing cultural diplomacies of Melkites and Latins towards the French as a source of sponsorship.

Hajjar's Francophilia did not exclude an openness to the English language, however; the Haifa school, for example, provided both French and English classes. ${ }^{54}$ Hajjar was also not always content with his French benefactors. Taking advantage of the British Mandate, he also sought Anglophone donors, as seen in a report written in English on his works in 1929. This letter states that "adopting" a small school with a single teacher costs 400 dollars per year, suggesting that he was reaching out to communities in North America. ${ }^{55}$ It is thus possible to observe that education in French and teaching of the French language was a multidirectional set of relationships, in which the French state sought to attract the sympathy or even loyalty of the Melkite communities, while the Melkites themselves juggled different sponsors in a bid to maximise their resources.

\section{The Melkites Between Diplomacy and Cultural Diplomacy}

The Melkite deployment of cultural diplomacy as a means of asserting themselves, as a small regional minority, to make demands on various states did not begin with the Mandate period. When, during Ottoman rule, Jamal Pasha expressed to France his dissatisfaction with the opinions of Archbishop Dimitrios Qadi, locum tenens of the patriarchal seat, the latter responded by pointing out that the community's loyalty would come with better treatment from the Ottoman government: "And what do we hold against the State? Let it open schools for our children and build hospitals for our patients and do what France has done and we will prefer it over all other states". 56

Archbishop Grigorios Hajjar was equally willing to aim similar arguments at the French. In 1906, during his visit to Beirut, Hajjar complained to the French consul that the Melkite Patriarch Cyril VIII Geha was not treated like

\footnotetext{
${ }^{53}$ ASS 3, fol. 29-38: The author considers that Hajjar is doing his best to fight the apostolate of Latin missionaries in Palestine. This letter was retrieved from the Post Office and was never sent to its real addressee who was probably a prelate from Belgium asking for information about Hajjar's requests for financial help.

${ }^{54}$ ASS 1, fol. 62. Bāsha, Tārikh al-țayyib al-athar, 65.

${ }^{55}$ Grigorios Hajjar, My work during 1929 (No publisher known), 3.

${ }^{56}$ Ilyas Andraos, "Wafāt al-mūthallath al-raḥamāt al-bațriyark dimitrius al-awwal qādi bațriyark Anțākya wa al-iskandariyyah wa ūrashalīm wa sa'ir al-mashreq," Al-Masarrah 11 (1925): 688.
} 
his counterparts. In fact, the French consul was upset because the Melkite Patriarch organised a banquet in honour of a German delegation. To settle this case, Hajjar advised him to "decorate" the Melkite Patriarch in the same way as his Maronite counterpart. ${ }^{57}$ The Patriarch would be thus decorated in 1911. The case was different with the Patriarch Cyril Moghaghab, elected in 1925 and therefore under the French Mandate; he was decorated the following year. ${ }^{58}$

Under the French Mandate over Lebanon and Syria, the Melkites continued to take advantage of their "exceptional" relations with the French to preserve the rights of their community within a multi-confessional society. Patriarch Qadi at times adopted harshly critical tones when the French Mandate acted contrary to the well-being of his community. Following the decision of the High Commissioner of Damascus to replace a Melkite with a Greek Orthodox in the judicial administration, Patriarch Qadi demanded to know of the High Commissioner

How under the French regime, would the Greek Catholics be less well treated than under the Turkish regime and the regime of Faisal? Do you want to reward thus our unwavering attachment to France?59

This also applies to the post of mutasarref in Zahle whose holder had formerly to be Melkite, a tradition the French Mandatory authorities threatened to disrupt: "I do not think I owe to our friends the French what the Turks had done spontaneously for a very long time". ${ }^{60}$

This tension between Melkite and French also found a terrain in the educational field. In 1924, when the Public Instruction learned of the circulation of a French book published by the Germans in a Melkite school in Deir al-Qamar, a major village of the Chouf region, France decided to close the school. Patriarch Qadi tried to clarify this misunderstanding:

As for the issue of the book, it is an error committed with incontestable good will. The Director of the School of Deir al-Qamar, relying on the title of the book, The Destruction of Churches and Art Monuments on the Western Front, believed that it was to demonstrate German vandalism. Undoubtedly he should have examined the contents of the book. He neglected to do so, which is unfortunate. But the error is explicable. Often in the schools, we do not read all the books [...]. The Germans gave their book a title that raises no suspicion. The engravings leave nothing to guesswork either. To realize the spirit that animates the author, we should read the text. We did not do so, we just read the title and saw the engravings. It is a regrettable negligence, that is well understood; but it

\footnotetext{
${ }^{57}$ Rabweh, PM, GH 1 fol. 28.

${ }^{58}$ No author, "ghibțat al-bațiyark fì Bayrūt," Al-Masarrah 2 (1926): 114.

${ }^{59}$ Rabweh, PM, Reg. DQ p. 213 (N2/57) 15 December 1922.

${ }^{60}$ Rabweh, PM, Reg. DQ, 214 (N2/63) 26 December, 1922.
} 
does not deserve the sanctions that the Department of Public Instruction has thought it necessary to impose.

An establishment which has always distinguished itself by its attachment to France, which has always deserved the complete satisfaction of the French Authorities; which excites jealousy among certain circles cannot be sentenced to closure. ${ }^{61}$

In the example cited above, formal diplomatic relations and cultural diplomacy intertwine, at times uncomfortably. This tension is less present in Palestine because it was under a British Mandate and French and Melkite interests tended to map more clearly onto one another. Grigorios Hajjar's activity, as we shall see, clearly reflects a two-way pattern of cultural diplomacy between the French and the Melkites.

\section{Grigorios Hajjar, an Agent of Cultural Diplomacy}

For Eastern Catholics in Palestine, France still embodied the Catholic Protectorate despite this arrangement's formal end under the British Mandate. ${ }^{62}$ The Consulate of France sustained its cultural action through religious congregations, cultural centres and financial support to Eastern communities, especially through its presence during liturgies or ceremonies that marked the life of the Melkite community. One example of this French presence was the 25th jubilee of the priesthood of Grigorios Hajjar (January 3-29, 1922). The magazine Al-Masarrah relates the presence of the French consul during the pontifical liturgies which inaugurated and closed this jubilee. ${ }^{63}$ After the concluding liturgy, the consul decorated Hajjar and congratulated on his own behalf and that of General Gouraud, High Commissioner of the French Republic in the Levant. No mention is made of an English presence at the ceremonies. The reader could easily believe that we are equally under the French Mandate.

But Grigorios Hajjar was not only a tool used by French diplomacy to achieve its cultural ends. He, too, was trying to benefit from his relations with the French for his own projects. He did not hesitate to get in touch with the French diplomats but also with French Catholics, trying to awaken in France the dream of the Crusades to solicit their generosity. In a seven-page printed pamphlet, in French, ${ }^{64}$ about his works in 1903 and 1909, addressed to the "benefactors of the Catholic Galilee", we read this introductory note:

\footnotetext{
${ }^{61}$ Rabweh, PM, Reg. DQ, 269-271. Letter of July 22, 1924 to General Weygand.

${ }^{62}$ Sanchez Summerer, "Le triptyque," 70.

${ }^{63}$ No author, “Akhbār Tā'îfiyya: ābrashīat 'Akkā,” Al-Masarrah (1922): 92-93, 140.

${ }^{64}$ Rapport des cuvves de S.G. Mgr Grigorios Haggear archevêque catholique de la Galilée 1903 et 1909. This pamphlet consists of the report presented to Pope Pius X in 1903 (five pages) and an overview of the year 1909 (two pages).
} 
The realised progress, at the same time as it will draw attention to the sum of what remains to be done, will encourage the Catholics of France to continue the endeavours of the Crusades, saving the country of Christ!

Hajjar considers France to be a Christian country despite the law of 9 December 1905 which established an official secularist policy and the separation of church and state. In a letter sent from Cairo to French benefactors on 30 November 1918, following the end of the First World War, ${ }^{65}$ Hajjar glorified France as the standard bearer of Christian civilisation. ${ }^{66}$ In a later letter, he mentions "its beautiful mission as educator and civiliser of humanity" ${ }^{67}$

Hajjar's school construction movement undoubtedly required external funding given the precarious economic situation of the diocese. Aware of the importance of francophony in Arab countries and of the power of French, Hajjar attempted to take advantage of his relations with the French authorities for the good of his diocese and also of the Melkite patriarchate. In a letter to the Melkite Patriarch in 1913, Hajjar talked about his trip to Paris and his meetings with top politicians. He mentioned pleading for the need to allocate special attention to the Melkite schools, particularly those in Jerusalem and its suburbs, as these schools were the only ones which taught the French language and sought to spread the language and to support French influence. According to Hajjar, the French party was very favourable to supporting the Melkites but the affair required time. He therefore advised the Patriarch, once this assistance was granted, to open schools throughout his territory at the expense of the French government or a French association. ${ }^{68}$ In an undated letter addressed to the Patriarch Qadi, Hajjar notes receiving 300

\footnotetext{
${ }^{65}$ During his visit to Paris in 1914 before the outbreak of the First World War, Hajjar met young Lebanese, Syrians and Palestinians wishing to join the French army to fight the Turks. As a result, the Turkish government no longer recognised Hajjar as archbishop of the Melkites of the Archbishopric of Saint John of Akka and he was sentenced to death. Hajjar only learned this news once back in Egypt. He was therefore obliged to remain there until the end of the war. Manșūr, Ru'ya mū'āsira, 63-66.

66 "Glory be to France! Flag bearer of Christian civilization; France, home of our hearts; Just as its soldiers have tied their history with unequalled Victory, we hope that France will bind its history in the victory of Christ, the august Prince of peace!... That by and with her, the nations united by the charity of Christ in the highest ideal recognize the flock of a single Pastor, the members of one family, even one body, of whom Christ is the head!" ASS 1, fol. 15.

${ }^{67}$ ASS 1, fol. 69.

68 "I took on pointing out to the authorities the importance of paying special attention to our confessional schools, particularly your Patriarchal schools in Jerusalem and its suburbs, showcasing that it is only the Patriarchal schools that teach and seek to spread the French language and endorse French influence... We were clearly heard; however, these matters require some time to be studied but will be brought to a successful end, by God's will and your Beatitude's supplication. If that happens, you can then inaugurate, in all your missions, flourishing schools at the expense of the government or a French association.” Rabweh, PM, GH 1,1 fol. 13.
} 
Francs from l'Eeuvre des Écoles d'Orient and a sum of 2000 francs in $1924 .{ }^{69}$ Hajjar had planned to build a select boarding school in Haifa with the collaboration of the Ministry of Foreign Affairs in Paris but the First World War put an end to this project. ${ }^{70}$

At the end of this study, certain elements deserve to be taken into consideration. France did not collaborate with another state but with a particular community, the Melkites, who had had their own history of relations with France for two centuries. The Melkites were widespread in Lebanon, Syria and Palestine, with a few in Egypt, while other Christian communities tended to be more concentrated in one country (Maronites in Lebanon, Syriac in Iraq and Copts in Egypt). The triple title of Patriarch (Patriarch of Antioch and All the East, Alexandria and Jerusalem) granted to Maximos Mazloum in 1838 is indicative of this aspect of the community's experience. The circulation of Melkites between these different countries is very evident, as attested by their archives. The largest presence of Melkites was in Syria and Lebanon, ${ }^{71}$ two countries under French mandatory rule since 1920 and, as a consequence, the influence of French action in Palestine overflowed territorial borders.

French cultural diplomacy towards the Melkites of Galilee was thus not limited to intervention by the public authorities. The intervention of non-governmental organisations and, in our context, the Catholic hierarchy, acquired considerable importance. The upkeep of certain Melkite schools by the French nuns of Notre Dame de Nazareth and the subsidies received from l'Euvre des Écoles d'Orient favoured the propagation of French culture. In addition, Hajjar solicited French Catholics to finance the construction and maintenance of these schools. As a result, state, churches and French Catholics were three inseparable and complementary agents in the conduct of French cultural diplomacy in Mandatory Galilee.

Grigorios Hajjar collaborated simultaneously with the political and ecclesiastical authorities, but these two authorities did not necessarily have the same priorities. The Catholic Church of France sought first and foremost to keep those coming from the oriental schism within the fold of the Roman Church, to bring back the schismatics to Roman obedience and also to propagate French culture. Consequently, close links existed between the spread of the French language and Catholicism in Mandatory Galilee. Aslanov's research even shows that the religious factor, well before colonial expansion, was at the

\footnotetext{
${ }^{69}$ Rabweh, PM, GH 1.2 fol. 25; Rabweh, PM, GH 1.2 fol. 32. Letter from Haifa, sent on June 3, 1924.

${ }^{70}$ Rabweh, PM, GH A fol. 12. A letter from June 24, 1933.

${ }^{71}$ The patriarchal seat is in Damascus and the cradle of its religious orders is in Lebanon (the Salvatorians at Joun, the Choueirites at Khenchara, the Paulists at Harissa).
} 
roots of the preservation of the French language in the East. ${ }^{72}$ French missionaries are therefore both "missionaries of faith and language". 73

The Melkites were aware of the advantages they acquired as Catholics in their relations with the French government: "Whatever their religious opinions are, the French are obliged to recognise that their most loyal customers, most active and most cultivated are the Catholics!"74 Public power and Catholic hierarchy were two inseparable elements in French cultural diplomacy in the East. Grigorios Hajjar took advantage of his religious and political network to build schools and churches in Mandatory Galilee where, despite his efforts, French was losing ground to English, Arabic and Hebrew, mastery of which was central to gaining access to administrative positions. ${ }^{75}$

\section{BIBLIOGRAPHY}

Al-Bahri, Jamil. "Akhbār Tā'îfiyya: ābrashīat 'Akkā.” Al-Masarrah 3 (1921): 137-139. —_. "Akhbār Tāōifiyya: ābrashīat 'Akkā." Al-Masarrah: majallat Batrīyarkìyat alRùm al-Kāthūlìk l (1924): 56-59.

—. Ghrighorios Hajjār mitrupul̄̄t'akkā wa Hayfā wa al-nāsirah wa sa'ir al-jalīl tarjamatahū a'mālūhū. Haifa: Mațba'at al-zahra, 1927.

Andraos, Ilyas. "Wafāt al-mūthallath al-rahamāt al-bațiyark dimitrius al-awwal qādi bațriyark Anțākya wa al-iskandariyyah wa ūrashalīm wa sa'ir al-mashreq." Al-Masarrah 11 (1925): 645-706.

Anon. "Mukātabāt." Al-Masarrah 6 (1911): 238-239.

_. "Ghibțat al-bațriyark fì Bayrūt." Al-Masarrah 2 (1926): 113-115.

_. "Abrashīat Urshalīm al-batrīrkīa." Al-Masarrah (1939): 385-399, 470-480.

Aslanov, Cyril. Le français au Levant, jadis et naguère. À la recherche d'une langue perdue. Paris: Honoré Champion, 2006.

Bāsha, Qusțanțīn. Tārikh al-țayib al-athar Ghrighorios Hajjār mutrān 'akkā wa Hayfā wa al-nāsira wa al-jalīl. Joun: Maṭba'at Deir al-Moukhaless, 1941.

Batārikh, Ilyas. "Ḥaflat taslīm wisām jawqat al-sharaf li ghibțat bațriyarkina al-kūlliyyi al- tūbā." Al-Masarrah 8 (1911): 313-317.

Dahbar, Nicolas. Sainte-Anne de Jérusalem Séminaire grec-melkite dirigé par les RR. PP. Blancs à l'occasion du 75 e anniversaire de sa fondation (1882-1957). No location: No publisher, 1959.

${ }^{72} \mathrm{Cf}$. Cyril Aslanov, Le français au Levant, jadis et naguère. À la recherche d'une langue perdue (Paris: Honoré Champion, 2006). On the link between the French language and the Catholic religion in Palestine cf. Sanchez Summerer's study on the colleges of Brothers of the Christian Schools of Jerusalem in Mandatory Palestine studied in Karène Sanchez Summerer, Politiques, éducation et identités linguistiques: Le collège des frères des écoles chrétiennes de Jérusalem (19221939) (Utrecht: LOT, 2009).

${ }^{73}$ Karène Sanchez Summerer, "Pour Dieu et la Patrie: Formation des missionnaires français envoyés au Levant (1880-1940). Le cas des frères des écoles chrétiennes," Documents pour l'histoire du français langue étrangère ou seconde 55 (2015): 2 .

${ }^{74}$ Rabweh, PM, Reg. DQ, 283. Letter sent to the director of the Saint Sulpice seminary, abbé Vigourel.

${ }^{75}$ Sanchez Summerer, "Les catholiques palestiniens," 7. 
De Sarepta, Jean. L'Eglise catholique-grecque en Galilée. Paris: Imprimerie de F. Levé, 1890.

Dimitrius, Qādi. “Testament de S.B. Dimitrios Cadi." Al-Masarrah 11 (1925): 709-710.

Dueck, Jennifer. "International Rivalry and Culture in Syria and Lebanon Under the French Mandate." In Searching for a Cultural Diplomacy, edited by Jessica Gienow-Hecht and Mark Donfried, 137-161. New York: Berghahn, 2010.

Freijat, Faez. "La biblioteca del convento de San Salvador (Ğūn)." In Manuscritos árabes del Líbano, Encuentro de culturas, religions y saberes, edited by Philippe Roisse, 57-72. Beirut: Cedrac, 2010.

Gorra, Philippe. Sainte-Anne de Jérusalem Séminaire grec melkite dirigé par les Pères Blancs à l'occasion du son cinquantenaire (1882-1932). Harissa: Press Saint Paul, 1932.

Haiduc-Dale, Noah. Arab Christians in British Mandate Palestine: Communalism and Nationalism 1917-48. Edinburgh: Edinburgh University Press, 2013.

Hajjar, Grigorios. My Work During 1929. No publisher known.

- Mes auvres en 1936. No publisher known.

Kabkab, Wisām Bishārah. Ayn Trāz, 1811-2004: Iklīī̄īyat Sayyidat al-Bishārah al- Batriyarkīyah wa-al-maqarr al-Batrīyarkī. Rabweh: Markaz al-Abhāth al-Malakīyah, 2008.

Kuwaytir, Ilyas. Al-akimma al-nayyira. Joun: Manshūrāt al-Yūbīl al-Mi'awī al-Thālith lil- Ruhbānīyah al-Mukhallisīiyah, 1993.

- Al-Rubbān̄̄ya al-Mukhallișìya manāra mushi'a fì al-arāḍ̄ al-muqaddasa. Joun: Manshūrāt al-Yūbīl al-Mi'awī al-Thālith lil-Ruhbānīyah al-Mukhallịīyah, 1997.

Manșūr, Johnny. Ru'ya mū'āsira lihayāt wa a'māl al-mutrān Ghrigurius Hajjar. Haifa: No publisher, 2013.

Milton-Edwards, Beverley. Islamic Politics in Palestine. London: I.B. Tauris, 1999.

Qarūshān, Ighnātius. "Haflat yūbīl ghibțat abīna al-bațriyark kirillūs al-thāmin al-kūlliyyi al- țūbā." Al-Masarrah 3 (1910): 82-91.

Qattān, Basīliyus. "Khūtāb siyādat al-mutrān kīriūs Basīliyus Qattān mitrupulīt Bayrūt wa Jūbayl wa tawābi ihimā.” Al-Masarrah 5 (1921): 213-221.

Raheb, Abdallah. Conception de l'union dans le patriarcat orthodoxe d'Antioche (16221672). Rome: Pontificia Universitas Gregoriana, 1981.

Sanchez Summerer, Karène. Politiques, éducation et identités linguistiques: Le collège des frères des écoles chrétiennes de Jérusalem (1922-1939). Utrecht: LOT, 2009.

_. "Les catholiques palestiniens et la langue française (1870-1950)." Documents pour l'histoire du français langue étrangère ou seconde 45 (2010): 17-42.

- "Le triptyque 'Langue - Education - Religion' dans les écoles missionnaires françaises de Jérusalem en Palestine ottomane et mandataire." Sociolinguistica 25 (2011): 66-80.

- "Pour Dieu et la Patrie: Formation des missionnaires français envoyés au Levant (1880-1940). Le cas des frères des écoles chrétiennes." Documents pour l'histoire du français langue étrangère ou seconde 55 (2015): 83-99.

Sayyūr, Būlos. "Mukātabāt." Al-Masarrah 18 (1912): 717-718.

Trimbur, Dominique. "Sainte-Anne: lieu de mémoire et lieu de vie français à Jérusalem." Chrétiens et sociétés XVIe-XXe siècles 7 (2000): 39-69.

Yazbak, Mahmoud. Haifa in the Late Ottoman Period, 1864-1914: A Muslim Town in Transition. Leiden: Brill, 1998. 
Open Access This chapter is licensed under the terms of the Creative Commons Attribution 4.0 International License (http://creativecommons.org/licenses/ by $/ 4.0 /)$, which permits use, sharing, adaptation, distribution and reproduction in any medium or format, as long as you give appropriate credit to the original author(s) and the source, provide a link to the Creative Commons license and indicate if changes were made.

The images or other third party material in this chapter are included in the chapter's Creative Commons license, unless indicated otherwise in a credit line to the material. If material is not included in the chapter's Creative Commons license and your intended use is not permitted by statutory regulation or exceeds the permitted use, you will need to obtain permission directly from the copyright holder. 